\title{
The potential effects of climate change on the habitat in Southern Mexico
}

\author{
J. F. Audefroy \\ Escuela Superior de Ingeniería y Arquitectura (ESIA-Tecamachalco), \\ National Polytechnic Institute IPN, Mexico
}

\begin{abstract}
This study evaluates the potential effects of climate change on the habitat and human settlements in Mexico through an analysis of three regions that are vulnerable to hydrometeorological hazards, such as droughts, floods and hurricanes. The research process included fieldwork in the states of Oaxaca, Tabasco and Yucatán, and a historical study of hydrometeorological events in each region. We sought to identify a means of interpreting these events linked to climate variability on the basis of the history of disasters, the environment and the habitat. The local climatic indications were compared with the Intergovernmental Panel on Climate Change's global successes to show that contradictions do not exist but that it is difficult to apply the IPCC's findings at a local level, given the considerable margin of uncertainty. The indications of the effects of climate change make it possible to foresee that the most vulnerable populations will be the ones facing the strongest impact in the future. Our research has direct implications on urban and housing policies, offering a roadmap to design climate change adaptation strategies; the possibility for adaptation not only requires political commitment, but is also related to social and economic development and an "integral risk management" approach, rather than a "civil protection" strategy

Keywords: climate change, habitat, risks, hydrometeorological hazards, Mexico.
\end{abstract}

\section{Introduction}

Although there is no "theory" as such on adaptation to climate changes, several theoretical positions regarding this theme have been produced within the fields of history and anthropology. Some communities have also developed adaptive 
strategies of a social, technical and cultural type to face environmental and climate changes. This is a way in which traditional habitats have been adapting to different climates. From the perspective of political ecology, Oliver-Smith [1] has made several contributions to the subject, stating that disasters result from a historically constructed pattern of vulnerability that is based on location, orientation, existing infrastructure and the sociopolitical conditions. Disasters are thus complex, non-lineal, multicausal and multifactorial processes. In addition, there is a climate-oriented approach to risks based on a systemic analysis produced by Pigeon [2]. He states that disasters comprise a "feedback" phenomenon, that there is an interaction between the different variables or parameters, and that there is not necessarily a cause-effect relationship between the different aspects of a disaster.

In a recently published article, Pelling [3] considered that adaptation in response to any geological or hydro-meteorological event may imply material or institutional changes. In the habitat field, changes can be applied to the decisionmaking structures or to the construction design, materials, or standards (as was the case in Mexico City following the 1985 earthquake). At a local level, the adaptation process can be conducted through families, communities, and/or local authorities.

Based on the study of three different cases in Mexico located in the states of Oaxaca, Tabasco and Yucatan regarding three different phenomena - drought, floods and hurricanes - we shall observe the adaptive practices followed by communities and municipalities to face the effects that climate change has on habitat. In the first case (Tilantongo in Oaxaca State) recurring drought forced both communities and authorities to take measures to harvest and store water both for human consumption and crops. In the second case (Villahermosa in Tabasco State), the floods in 2007 forced the state to displace the affected populations to new housing settlements beyond the floodplains. In the third case (San Felipe and Cacalchen in Yucatan State), following Hurricane Isidore in 2002, the authorities conducted a reconstruction program comprised of basic housing units in the same plots of land affected by the hurricane. These three adaptive strategies designed to deal with climate variability posit different issues. This piece of research assessed the difference in vulnerability among families, beyond the effects of climate change as a combination of socio-economic inequalities and habitat type vis-à-vis exposure to natural threats, droughts, floods and hurricanes. Lastly, it conducted a comparative evaluation of local climate trends vis-à-vis large-scale trends identified at a global level by the Intergovernmental Panel on Climate Change (IPCC).

In view of the fact that few studies have integrated a spatial dimension into the human-climate-environment relationship, this piece of research introduced habitat as a new element in climate anthropology.

In the presence of climate variability, such as drought, floods or hurricanes, this variation impacts both community and habitat. These three elements, climate, community and habitat are physically and symbolically intertwined. 


\section{Background information: three case studies}

La Mixteca Alta, inhabited by Mixteco people (ñuúsavi), is located in Oaxaca State and Tilantongo is one of the 32 municipalities of the Nochixtlán District. Except for the municipal seat, Tilantongo is comprised of dispersed settlements formed by ranches far from the administrative center. Ninety per cent per cent of the municipality's population is estimated to live on ranches. The climate in La Mixteca Alta is mainly dry. It is nonetheless considered to have a temperate climate. Although it rains in the summer, the humidity levels are low. The rest of the year there is little or no precipitation. Except for the period from 1989 to 2001, it could be said that there is drought in Oaxaca State every five years, having suffered the experience of extreme drought in 1982. The lowest annual rainfall in Nochixtlán District was $322 \mathrm{~mm}$ between 1926 and 1930; $427 \mathrm{~mm}$ between 1945 and 1948 (Butterworth [4]) and $440 \mathrm{~mm}$ in 1984 (INEGI, 1984). The inhabitants' memories confirm these figures. The annual average for Oaxaca State between 1961 and 1990 was 1,349.60 mm (Martínez Austria and Patiño Gómez [5]).

The city of Villahermosa in Tabasco State is located in the watershed of the Grijalva and Usumacinta rivers. In pre-Hispanic times, it was a favorable place for agricultural development and a water-based civilization. The hydraulic works constructed by the Chol and Chontal peoples provide testimony of this. In the studied period (from 1652 to 2008) in which hydro-meteorological events were recorded, there was recurrent flooding particularly in September, October and November. The catastrophic flood in October 2007 was not an isolated phenomenon. Based on this information, an overflow rate of two events every ten years can be estimated for precipitation of over $500 \mathrm{~mm}$ and a rate of 1.33 events for precipitation over $700 \mathrm{~mm}$ every ten years.

In Yucatan State, hurricanes, their effects and the reconstruction program, in particular as a result of Isidore in September 2002, were considered. We analyzed two case studies. The first was carried out in Cacalchen, located $41 \mathrm{~km}$ east of Merida City, and the second one took place in a fishing village called San Felipe on the northern coast of Yucatan. Geographically and ecologically speaking, these two villages are very different from each other. Cacalchen is located in the old production area of henequén, an agave from which a fiber resembling sisal is obtained, an area in which the traditional Mayan dwelling prevailed, a house made of bajareque (a lattice made of sticks and mud) or stones with an apsidal roof made of huano palm leaves. San Felipe is a fishing village in which the houses are made of wood with a gable roof made of huano or tin sheets. The two villages were severely affected by Hurricane Isidore. 


\section{Climate trends observed in Oaxaca, Tabasco and Yucatan States}

\subsection{In Oaxaca State}

It is interesting to observe that different sources of information evidence an alternation between drought, abundant rainfall and frosts. From an historical perspective, it can be deduced that at least since colonial times to date the same phenomena have appeared in succesion. These phenomena have been recurrent, although varying alternations. In the period from 1970 to 2011, it can be observed with more precision that drought was a recurrent theme among the Oaxacan and Mixteco populations. In this same period, in accordance with a database called desinventar (an online inventory system of the effects of disasters produced by La Red for North, South and Central America), a recurrence of drought was observed (Fig. 1):

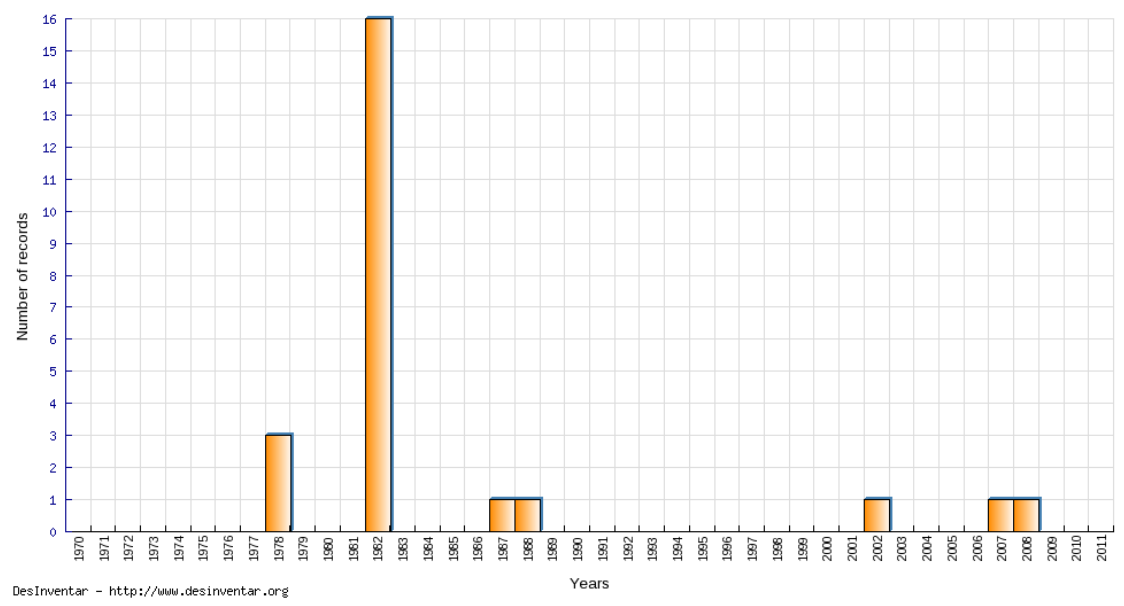

Figure 1: Drought in Oaxaca State in 1970-2011 (source: Desinventar. available at: http://www.desinventar.org).

In this same period, from 1997 to 2011 there were intense rainfalls. Prior to that period, intense rainfall was sporadic. It can be observed that the El Niño phenomenon in 1998 did cause intense rainfall in Oaxaca State, although it was less intense than in 2010 and 2011.

\subsection{In Tabasco State}

Historical data reveal that the risk of floods in Tabasco State is a social construction due to anthropogenic activity over time: river diversion, tree felling and the introduction of cattle-ranching have contributed towards changing the state's ecosystems and hydro-geological context. In the 1940s, unprecedented intense deforestation was noted in the region (Tudela [6]). 
The following graph regarding the number of floods for the period from 1979 to 2011 was obtained from the Desinventar database:

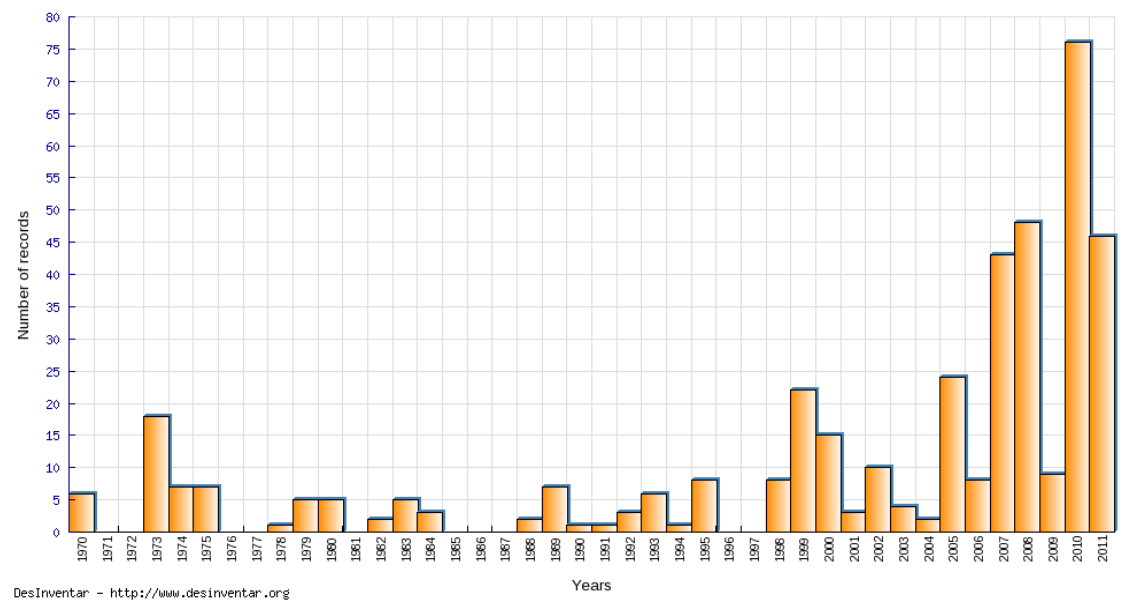

Figure 2: Number of floods in Tabasco state in 1970-2011 (source: http://online.desinventar.org/).

Figure 2 shows that the number of floods in Tabasco State was higher since 2005 with high peaks in 2007, 2008, 2010 and 2011. This fact has led researchers to associate these floods with the effects of climate change in Tabasco State for those years. We shall nonetheless consider these statements as an unproven hypothesis.

\subsection{In Yucatan State}

Of the 54 hurricanes and tropical storms recorded to have affected the Yucatan Peninsula since the Conquest up to 2009, in total 13 hurricanes left an imprint. Taking into account another four hurricanes that approached the peninsula in recent times, the figure raises to a total of 17 .

Thanks to Desinventar.com there is more reliable data for the period from 1970 to 2011. This database provides information on floods and rainstorms in Yucatan State corresponding to tropical storms and hurricanes.

Figure 3 demonstrates that hurricanes have generated floods and rainfall that were not that frequent in earlier decades. Statistics show that in the later 14 years, i.e., from 1998 to 2011, these phenomena increase. During the period from 1995 to 2007, six high-intensity hurricanes were recorded in Yucatan. Both the rainstorm and flood graphs, and recorded hurricanes show certain changes in hydro-meteorological phenomena in the last two decades. The higher intensity of hurricanes and the abundance of floods and rainfall seem to be pointing towards a new trend. Of course, not all hurricanes qualify as disasters. However, during 
the period from 1980 to 2007, twelve hurricanes in the Gulf/Caribbean could be considered disasters. The hurricane category does not necessarily coincide with its destructive impact. For example Isidore (Cat. IV, 2002) with a lower category than Gilbert (Cat. V, 1988) resulted in much more devastating effects. It is worth asking what might have happened with these hurricanes if society were less vulnerable, if the environment were less destroyed and if there were a greater recovery capacity and a more developed resilience.

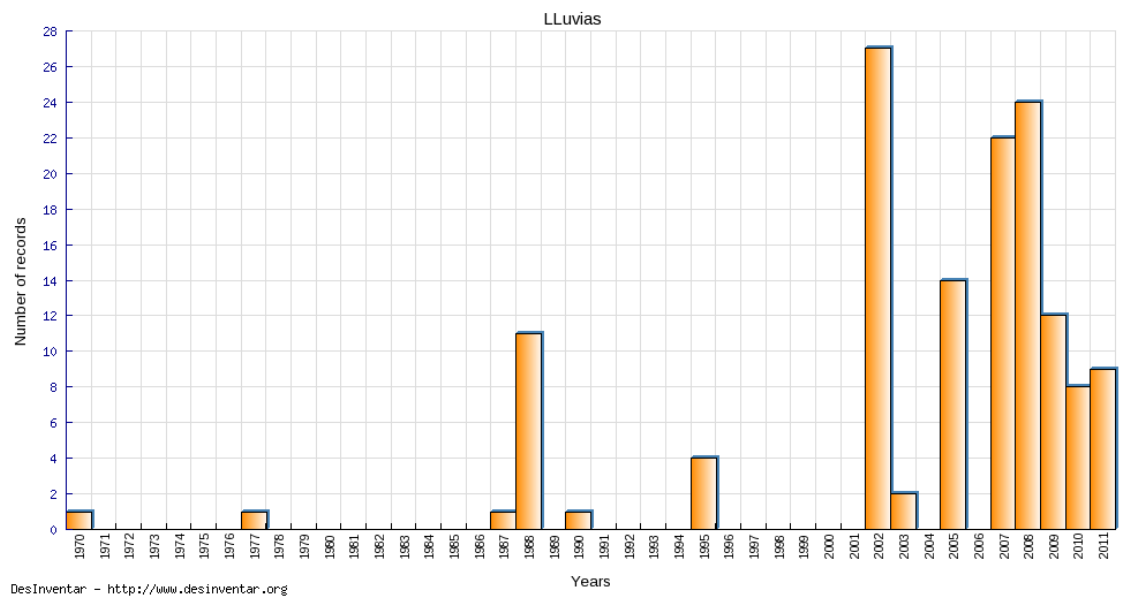

Figure 3: Rain storms in Yucatan state in 1970-2011 (source: http://online.desinventar.org/).

\section{Drought and its impact on habitat}

The IPCC posits that climate change will affect, "water resources in some dry regions at mid-latitudes and in the dry tropics, due to the altering of precipitation and evapotranspiration, and in areas dependent on snow and ice melt" (IPCC [7]). What we have observed in the Mixteca Alta in Oaxaca State would seem to confirm this statement. Water availability will not only affect crops (more high-risk crops will be needed), but will also affect habitat. As has been observed in the Mixteca Alta, the habitat is scattered and water availability for home use will be affected. Many rivers are drying out, some water springs are decreasing, and there is a higher risk of uncontrollable forest fires. As far as health is concerned, there is a higher risk of mortality due to temperature-related causes, particularly among the elderly. In tropical zones located under 1500 meters above sea level the quality of life has worsened owing to temperature increase. Adequate housing is lacking. Precarious housing does not offer enough thermal steering to curb the effects of excessive heat. Houses have tin roofs and walls made of wooden planks, asphaltic cardboard or tin sheets. Traditionally constructed houses made of adobe or stone offer high thermal steering that limits heat inside the house. 
Cases of drought in Mexico have been well documented: Sánchez-Mora [8]; García Acosta [9], and Florescano and Swan [10] set forth a chronology of droughts dating from the year 1500 to the twentieth century. As we have seen in the case of Oaxaca, recurrent drought has been an ongoing feature.

\subsection{What are the future implications of drought?}

According to Hernández Cerda et al. [11], of the seven processes associated with drought-produced desertification, three have a direct impact on habitat:

- Degradation of the vegetable layer (deforestation): In general, this is an anthropogenic process rather than a natural phenomenon. However, drought also contributes to deforestation. Deforestation implies consequences on habitat: trees protect houses from wind, encouraging a micro-climate that limits surplus heat. They are an excellent renewable resource and offer construction materials that are less polluting than cement production.

- Water erosion: it is the process of soil removal due to the action of water. Erosion may lead to landslides and differential settlement of housing foundations thus affecting construction. Alternate cycles of drought and rainfall particularly affect the soil, especially the topsoil.

- Wind erosion: the detachment and shedding of soil particles caused by wind. The shedding of particles may affect constructions, particularly those made of adobe that are impacted by wind and air-transported rain.

Desertification usually decreases soil resistance. Thus, some soils that used to be suitable for construction become unsuitable and may generate settlements at risk. According to Hernández Cerda, "the soil and most of the dry land elements are in general resistant and able to recover after suffering climate alterations and man-made effects, such as deforestation. However, when land is degraded, its recuperation capacity is substantially reduced, which implies physical and socioeconomic repercussions."

Hérnandez Cerda et al. [11] note that "the region of Oaxaca constitutes a case in which the 1972 drought had disastrous effects on a destabilized ecological system." Environmental alterations caused by human activity and the prevalence of subsistence crops that are highly vulnerable to drought brought about serious economic loss, and affected social issues.

On a local or regional level, it is difficult to identify whether drought and temperature increases are caused by climate change or deforestation. In fact, it is difficult to differentiate climate causes from others types of causes such as anthropogenic activity. According to the IPCC [7], the observations obtained in all continents evidence that many natural systems are being affected by regional climate changes, particularly by temperature increase. These alterations, however, also result from local human activity, such as deforestation and grazing in what used to be arable soil. 


\section{Impact of hurricanes and floods on human settlements}

\subsection{Why are the Mexican Caribbean coasts now more vulnerable to hurricanes?}

In order to evaluate the vulnerability of the Caribbean coasts to hurricanes, coastal population growth must be taken into account. At a national level, from 1940 to 1950 the urban population inhabiting coastal locations doubled from 606 thousand to 1.2 million inhabitants (Hernández Cerda et al. [12]). In 1995, the coastal urban population increased to 12.6 million and the coastal population in the Caribbean-Gulf of Mexico region went from 1,069,357 in 1950 to 4,891,572 inhabitants in 1995 (INEGI, 1996). In other words, it quadrupled in 40 years. From 1950 to 1960 , smaller locations also grew. For the fishing town of San Felipe, which we studied, out of a total of 1,789 inhabitants (2010), 1,769 inhabitants are considered vulnerable to sea level growth. It is known that during Hurricane Isidore in 2002, sea level rose $1.50 \mathrm{~m}$ throughout the village.

\subsection{Will hurricanes become more intense in the future?}

If we look at the cyclone intensity in the Yucatan Peninsula since 1980, we can observe 12 hurricanes considered "disasters," i.e., with a high level of intensity (category III, IV and V). As noted above, during the 1970s, 1980s and early 1990s, intense hurricanes were less frequent than in earlier decades. However, since 1995, intense hurricanes have become much more frequent. This is what the IPCC projects for the future:

Based on a range of models, it is likely that future tropical cyclones (typhoons and hurricanes) will become more intense, with larger peak wind speeds and more heavy precipitation associated with ongoing increases of tropical sea-surface temperatures. IPCC [7].

\subsection{Will hurricanes be more numerous and intense in the future?}

The IPCC [7] shows data pointing to an average heating of at least $1^{\circ} \mathrm{C}$ on the sea-surface, which favors the formation of hurricanes and other phenomena never before recorded, such as the first hurricane in the southern Atlantic in the Brazilian state of Santa Catarina in March 2008. The information that we have collected on the Yucatan Peninsula does not allow for a confirmation of a clear trend regarding hurricane and tropical storm intensity and frequency.

\section{Adaptations, mitigations and resilience}

The adaptation issue is nothing new. As García Acosta [13] highlights, "societies, throughout the world, and throughout history have developed social and cultural pathways to manage risks and face real and potential disasters. Societies are not, nor have been passive subjects in the face of natural threats." The IPCC also accords with that idea, "Societies across the world have a long 
record of adapting and reducing their vulnerability to the impacts of weatherand climate-related events such as floods, droughts and storms" (IPCC [7]).

\subsection{Habitat adaptation to climate variability}

The case studies in Tabasco, Yucatan and Oaxaca States have demonstrated that housing's vulnerability to flooding does not depend so much on external factors such as rainfall and storms, but rather on internal factors such as exposure, location or design. In fact, a house that is hardly exposed to flooding because of its location will not be affected by rainfall and will not be at risk.

Construction design can take into account high precipitation rates, for instance, through the use of pilings, like those used in stilt house settlements. In Tabasco State, after the flooding in 2007, the Tabasco Housing Institute (Instituto de Vivienda del Estado/INVITAB) constructed 120 stilt houses in the municipalities of Centla, Centro, Cunduacan, Jonuta and Macuspana. As a result of the floods in 2007, the same institution carried out a reconstruction program in Villahermosa in three housing complexes, but in none of them were houses constructed on stilts. None of the houses had lofts, either. In other words, no lessons were learned from the floods in 1999 and 2007. The design of low-cost housing in Tabasco continues the same as before the catastrophic events.

So far, the best drought adaptation processes in Oaxaca State have been conducted by the Department of Agriculture (SAGARPA by its acronym in Spanish), thus promoting roof harvesting of rainwater to be stored in tanks. In the face of a deteriorated environment, the Municipality of Tilantongo designated an ecological area of 3 thousand hectares of oak forest to be preserved and approximately 300 hectares have been reforested. However, adaptation activity is relatively scarce and the municipal seats have done nothing to harvest water or promote sustainable technologies.

As a result of Hurricane Isidore in 2002, in Yucatan, the FONDEN program (the National Fund for Disaster Relief), changed settlement patterns, introducing a $22 \mathrm{~m}^{2}$ cement block core house in the middle of traditional plots with a design that is foreign to the Mayan house, ignoring the tropical weather and the local context in Yucatan. All FONDEN core houses followed the same pattern, both in floodable areas (San Felipe) located on unstable soil and in zones suitable for construction (Cacalchen).

Mexico does not have an adaptation policy or strategy to face climate variability. Even though there is a National Climate Change Strategy, and Municipal Climate Action Plans at a local level (PACMUN), there is no housing policy, and in particular no low-cost housing policy that takes hydrometeorological threats into account. The adaptive capacity is not only related to political will power, but also has to do with social and economic development. The IPCC posits it as follows, Adaptive capacity is intimately connected with social and economic development, but it is not evenly distributed across and within societies. IPCC [7]. 


\section{Conclusions}

The population sector is currently more vulnerable and exposed to consequences attributable to climate change. Although the business sector is also exposed (as shown by the Global Assessment Report No. 13 [14]), it has the means (insurance and government support) to recover from disasters. The effects of climate change have a direct incidence on the correlation between development and justice in the exposed populations. The gap is opening more and more as impacts and disturbances become stronger in different realms: the economy, society, equality, service accessibility, territory and security. The most developed sectors have greater access to information and greater possibilities of achieving resilience and mitigating immediate consequences. The sectors that struggle on a daily basis in order to achieve a more decent life will be facing more difficulties to mitigate the effects of disasters. They are caught between an "assumed freedom" and the governments' authoritarian actions that condition their reconstruction programs, ignoring the specificities of vulnerable groups.

In the medium and long term, in the dawn of the twenty-second century, the more vulnerable populations will undoubtedly face a scarcity of drinking water and an increase in its cost, as well as an increase in the risks caused by landslides and floods, particularly in densely populated areas on the coast. Other populations will face drought in some areas and its immediate consequences: temperature increase (which places the whole issue of energy cost at stake). Others will also be facing more intense or longer lasting hurricanes that will endanger the family economy, which, to start with, is precarious enough.

This research also revealed that whereas urban development actors are in charge of assisting the populations affected by hydro-meteorological events, through applying reconstruction programs, they are contributing towards an increase in the risk of suffering disasters and catastrophes. In fact, this research demonstrates that the development of human settlements and ensuing inappropriate practices, are not only affected by climate change, but are also one of its main causes, since they might:

- Increase vulnerability;

- Increase exposure to extant risks;

- Intensify/amplify urban risk and create new risks;

- Lead to vulnerability and the risk of constant change (which makes them practically impossible to control);

- Reduce the capacity to face risk at a national and municipal level; and

- Reduce the capacity that low-income households and communities have to respond locally, as in the three cases.

In addition, vulnerability variables were identified to underlie the complex system of risk and disaster occurrence in poor neighborhoods, in urban neighborhoods, and also in rural and semi-rural settlements. This situation of social vulnerability intensely promotes the vicious circle of existing poverty in which people are trapped.

To conclude, like the IPCC, we must be prudent regarding climate change: disasters are multi-causal and at the same time result from a population's high 
vulnerability, human action in the environment and the effects of climate change. But this can only be demonstrated locally, as we have analyzed in the three aforementioned case studies.

\section{Acknowledgement}

The current work is a spin-off from research SIP: $N^{\circ} 20131120$, funded by the Research and Postgraduate Department (Secretaría de Investigación y Posgrado) pertaining to the National Polytechnic Institute of Mexico (Instituto Politécnico Nacional).

\section{References}

[1] Oliver-Smith, A., Theorizing vulnerability in a globalized world: a political ecological perspective. In: Bankoff, G., Frerks, G., Hilhorst, D. (Eds.), Mapping Vulnerability, Disasters, Development \& People, Earthscan, London, pp. 10-24, 2004.

[2] Pigeon P., Enjeux et vulnérabilités cachées: Evolutions récentes en géographie des risques. In: Risques et Environnement: recherches interdisciplinaires sur la vulnérabilité des sociétés, Becerra S. and Peltier A., L'Harmattan, Paris, pp. 53-64, 2009.

[3] Pelling, M., The Vulnerability of Cities to Disasters and Climate Change: a Conceptual Framework. In: Günter Brauch H., Oswald Spring U., et al., (Eds.), Coping with Global Environmental Change, Disasters and Security: Threats, Challenges, Vulnerabilities and Risks. Hexagonal Series on Human and Environmental Security and Peace, Vol. 5. Springer, Heidelberg, pp. 549-558, 2011.

[4] Butterworth, D., Tilantongo, comunidad mixteca en transición, INI, Mexico, 1975.

[5] Martínez Austria, P. F., Patiño Gómez, C. (Coords.), Atlas de vulnerabilidad hídrica en México ante el cambio climático, Efectos del cambio climático en los recursos hídricos de México, Vol. III, IMTA, Jiutepec, Morelos, 2010.

[6] Tudela, F., (Coord.), La modernización forzada del trópico: el caso de Tabasco, Proyecto integrado del Golfo, COLMEX-CINVESTAV-IFIASUNRISD, Mexico, 1989.

[7] IPCC, Cambio climático: Informe de síntesis. Contribución de los Grupos de trabajo I, II y III al Cuarto Informe de evaluación del Grupo Intergubernamental de Expertos sobre el Cambio Climático [Pachauri, R. K. and Reisinger, A. (publication directors)]. IPCC, Geneve, Switzerland, 2007.

[8] Sánchez-Mora, E., Las sequías en el México antigüo. In: Sancho y Cervera, J. (Coord.), Análisis histórico de las sequías en México, Documentación de la Comisión del Plan Nacional Hidráulico, Secretaría de Agricultura y Recursos Hidráulicos, №22, Mexico, pp. 15-20, 1980. 
[9] García Acosta, V., Las sequías históricas de México. In: Desastres y Sociedad, Red de Estudios Sociales en Prevención de Desastres en América Latina, Year 1, N¹, Mexico, pp. 83-96, 1993.

[10] Florescano, E. and Swan, S., Breve historia de la sequía en México, Universidad Veracruzana, Xalapa, Ver., Mexico, 1995.

[11] Hernández Cerda, M. E. et al., Mitos y realidades de la sequía en México, Textos monográficos, Vol. 6: Medio ambiente, UNAM, Mexico, 2007.

[12] Hernández Cerda, M. E. et al., Los ciclones tropicales de México, Textos monográficos, Vol. 6.1: Medio ambiente, UNAM, Mexico, 2001.

[13] García Acosta, V., Estrategias adaptativas y amenazas climáticas. In: J. Urbina Soria and Martínez Fernández J. (compilers), Más allá del cambio climático. INE-SEMARNAT/UNAM, Mexico, pp. 29-46, 2006.

[14] Naciones Unidas, GAR 2013, Evaluación Global sobre la reducción de riesgo de desastres, UNISDR, Geneve, 2013. 